\title{
AVIAN BOTULISM WITHIN EYEBROW MARSH, SASKATCHEWAN: 1988-1992
}

LYLE W. SAIGEON, Ducks Unlimited Canada, Box 4465, Regina, Saskatchewan. S4P 3W7

Eyebrow Marsh has a history of substantial waterfowl die-offs that have been attributed to avian botulism (Clostridum botulinum). Information gathered through the 1980 s and early 1990 s provides insight into the magnitude of waterfowl mortality and possible patterns associated with the incidence of the disease. Observations to date suggest that intensive water level management may not be a reliable means of reducing the regularity of occurrence or overall mortality. Projecting the timing of the first incidence of vertebrate carcasses, and expeditious removal of carcasses may be the most effective management tools. ${ }^{2}$

Here I describe and provide casual observations from Eyebrow Marsh over five consecutive years. Trends that relate current management practices to botulism occurrences and the usefulness of disease prevention and control efforts are discussed.

Eyebrow Marsh is situated within the mixed grass prairie of southcentral Saskatchewan (Figure 1) approximately $75 \mathrm{~km}$ northwest of Moose Jaw. Historically, the marsh existed as a 1,000-acre channel wetland along the floodplain of the Qu'Appelle River. Through the construction of impoundments and water control structures the flooded area was expanded to 2,200 acres of permanent marsh contained within five wetland management units. Eyebrow Marsh has a history of recurrent avian botulism.

Waterfowl botulism is a paralytic, often fatal, disease resulting from ingestion of toxin produced by the botulism bacteria, usually Type $\mathrm{C}$ toxin. Not enough is known about the factors that lead to an outbreak. Locke and Friend identify the important environmental factors that contribute to the initiation of avian botulism outbreaks as water depth, water level fluctuations, and water quality; the presence of vertebrate and invertebrate carcasses; rotting vegetation; and high ambient temperature. ${ }^{3}$ Wobeser et al. reported that despite the occurrence of suitable environmental factors and suitable bacterial substrate in most marshes the disease does not occur ubiquitously. ${ }^{5}$ While the bacterium is present within many prairie wetlands those marshes that have regular, severe outbreaks might have a much higher prevalence of spores within the upper sediments. Disease control measures to consider from a management perspective are: water level maintenance; projecting timing of the initial outbreak; and vertebrate carcass removal and disposal. ${ }^{2}$

Significant losses of waterfowl occurred during the period of 1988 to 1992 (Table 1). Despite inconsistencies in record keeping, it appears that dry conditions during the early to 


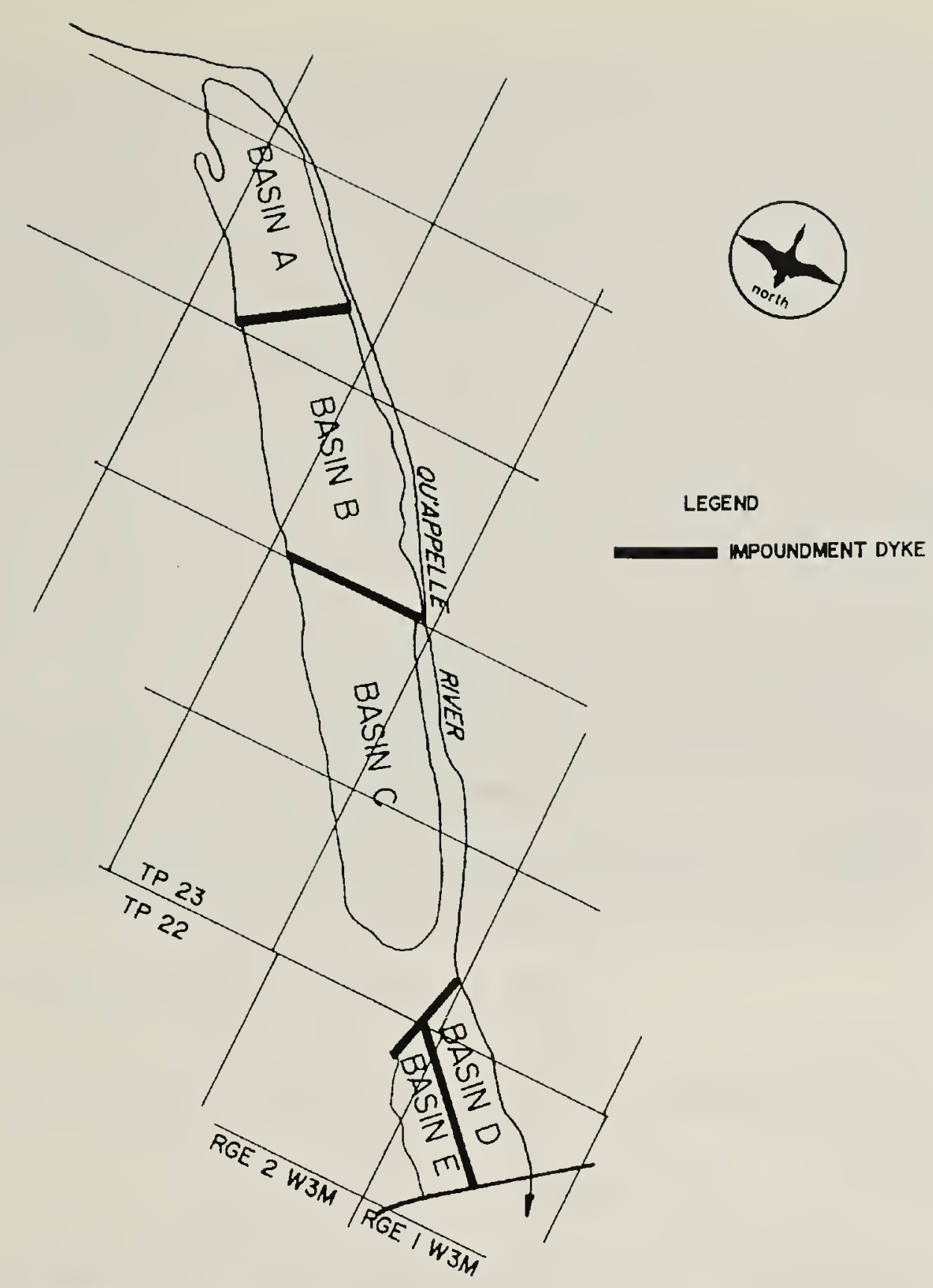

Figure 1. EYEBROW LAKE SKETCH PLAN.

mid-1980s probably resulted in very low waterfowl use with little or no subsequent die-off. No records were available prior to a large outbreak in 1981.4

Information collected from 1988 to 1992 suggests that there is some predictability in the timing of the initial outbreak. The first observation of casualties varied from 14 to 28 July with a median date of 21 July. This coincides wit. the peak period of moult for many waterfowl. Outbreaks persisted from four to six weeks although the duration of the disease was likely dependent on environmental factors such as daily ambient temperature, as well as waterfowl feeding behaviour and disease management efforts.
Total mortality and species composition is based on carcass removal. During the five years when significant losses were recorded it is known that the average mortality was a minimum of 3,300 waterfowl. Judging from the species composition of carcasses retrieved it appears that dabbling duck species compose $69 \%$ of mortality. Mallards consistently formed the largest portion of retrieved carcasses. Juvenile American Coots appear to contract the disease early. Botulism subsequently spreads through various other species of adult moulting ducks. The difference between the onset of moulting and foraging habitats of species may account for this progression and variation of mortality among species. 
Table 1. OCCURRENCE OF AVIAN BOTULISM

ON EYEBROW MARSH, 1988-1992

\begin{tabular}{||l|c|c|c|c|c||}
\hline & 1988 & 1989 & 1990 & 1991 & 1992 \\
\hline Period of outbreak & $\begin{array}{c}\text { 20 July - } \\
\text { 21 August }\end{array}$ & $\begin{array}{c}17 \text { July - } \\
\text { 27 August }\end{array}$ & $\begin{array}{c}\text { 28 July - } \\
\text { 22 August }\end{array}$ & $\begin{array}{c}\text { 26 July - } \\
14 \text { August }\end{array}$ & $\begin{array}{c}\text { 14 July - } \\
14 \text { August }\end{array}$ \\
\hline Total mortality & 3,000 & 1,012 & 351 & 4,790 & 4,202 \\
\hline \hline \multicolumn{5}{|l|}{ Species composition (\%) } \\
\hline Dabbling ducks & & 66 & 85 & 62 & 61.5 \\
\hline Mallard & 50.0 & 36.2 & 24.0 & 30.0 & 25.4 \\
\hline American Coot & & 19.3 & 8.0 & 20.0 & 15.1 \\
\hline Blue-winged Teal & & 10.6 & $\mathrm{n} / \mathrm{a}$ & 2.0 & 4.8 \\
\hline Northern Pintail & & 6.7 & $\mathrm{n} / \mathrm{a}$ & 15.0 & 7.2 \\
\hline Green-winged Teal & & 4.4 & 44.0 & $\mathrm{n} / \mathrm{a}$ & 12.0 \\
\hline $\begin{array}{l}\text { Duckling } \\
\text { (species not specified) }\end{array}$ & & 4.2 & $\mathrm{n} / \mathrm{a}$ & 8.0 & 0.7 \\
\hline \begin{tabular}{l} 
Unknown \\
\hline
\end{tabular} & & 4.9 & $\mathrm{n} / \mathrm{a}$ & & 15.6 \\
\hline
\end{tabular}

Table 2. WATER LEVELTEMPERATURE

VARIATIONS AT EYEBROW MARSH, 1988-1992

\begin{tabular}{|l|c|c|c|c|c|}
\hline & 1988 & 1989 & 1990 & 1991 & 1992 \\
\hline $\begin{array}{l}\text { Project segments with } \\
\text { significant botulism casualties }\end{array}$ & $\mathrm{B} / \mathrm{C}$ & $\mathrm{A} / \mathrm{B} / \mathrm{C}$ & $\mathrm{B} / \mathrm{C}$ & $\mathrm{B} / \mathrm{C}$ & $\mathrm{B} / \mathrm{C}$ \\
\hline $\begin{array}{l}\text { Water level }(\mathrm{M}) \text { change } \\
\text { from operating level }\end{array}$ & $-0.1 /$ & $-0.1 /$ & $+0.15 /$ & $0 / 0$ & $-0.15 /$ \\
$\begin{array}{l}\text { Change from normal annual } \\
\text { July/August temperature }\left({ }^{\circ} \mathrm{C}\right)\end{array}$ & +0.15 & $-0.1 /-0.15$ & -0.12 & & -0.2 \\
\hline
\end{tabular}

Specific environmental conditions are required for proliferation of the vegetative state of the bacteria following spore germination. The incidence of waterfowl botulism is more prevalent when wetlands exhibit shallow, stagnant water conditions as a result of prolonged hot weather. Managing wetland projects under a stable, high water regime should reduce the threat. Effort was made during the years of 1988 to 1992 to keep water levels high. Water level fluctuation was minimized by conveying minimal flows over the season at a rate that would offset evapotranspirational loss. Water level information compiled from 1988 to 1992 (Table 2) indicates July/ August levels were consistently held within 0.1 to $0.2 \mathrm{~m}$ of the full supply level. Continual flow from the Qu'Appelle River into the project basins resulted in improved water quality within the marsh.

Average monthly temperatures obtained for July and August of each year (1981 to 1992) are listed in Table 2. There was no indication that severe outbreaks coincided with unseasonably hot weather, however, it was revealed that regionally the average monthly ambient temperatures for the months of July and August are 26.1 and $25.2^{\circ} \mathrm{C}$, respectively. Locke and Friend report that optimal growth of the bacteria occurs at about $25^{\circ} \mathrm{C}$. It would appear that, at least in localized areas of Eyebrow Marsh, anaerobic substrate may reach this temperature by the third week of July. A more certain conclusion is that lessening water level fluctuations has not significantly 


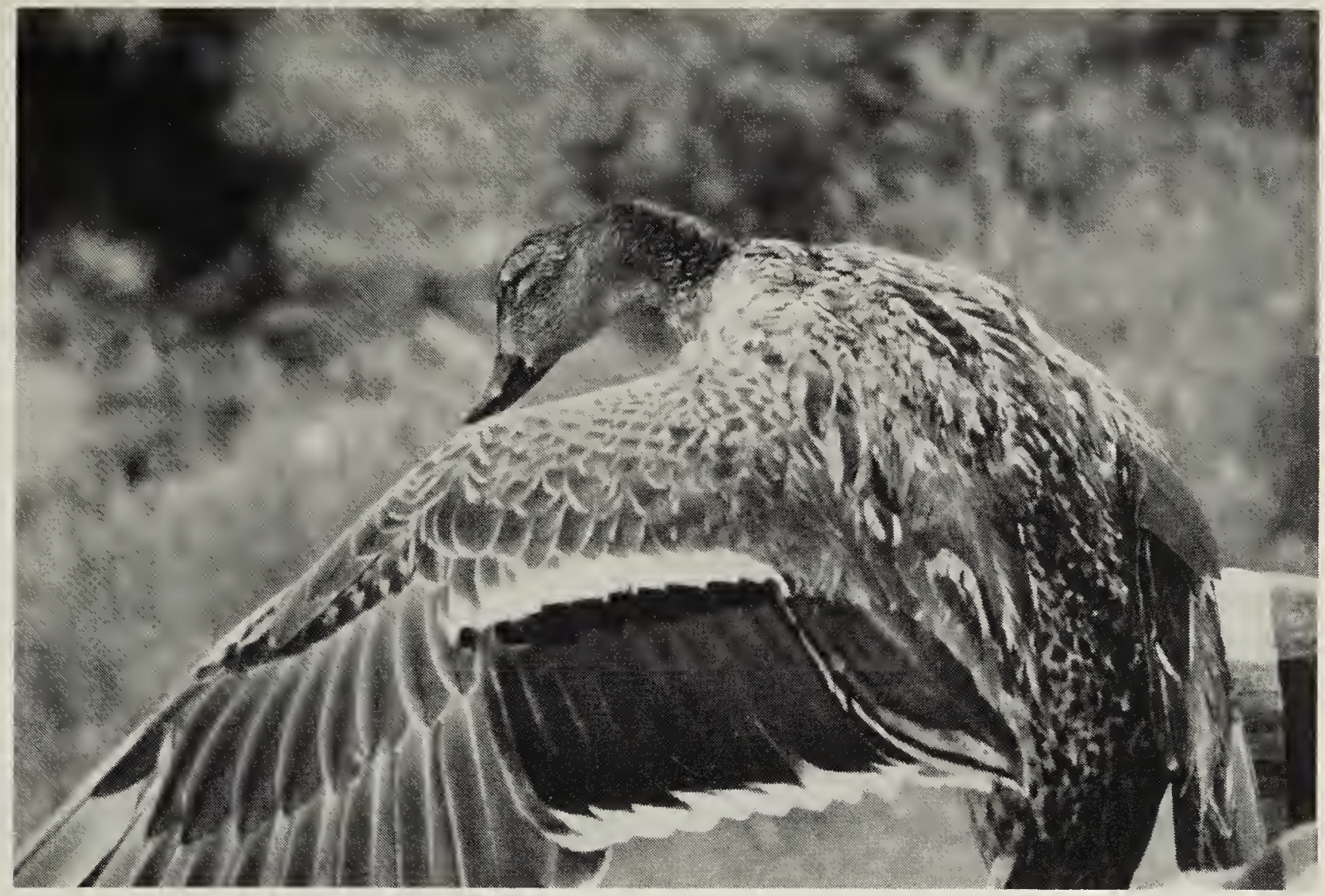

reduced the frequency of occurrence or the overall mortality on Eyebrow Marsh.

Other possible contributing factors linked to avian botulism include the presence of rotting vegetation and abundant invertebrate hosts. Portions of the marsh are very densely vegetated with Hardstem Bulrush. This provides good invertebrate habitat and adds substantially to the decaying detritus on the marsh bottom.

A final observation is that the presence of waterfowl carcasses rapidly escalates the spread of the disease. Floating carcasses are quickly infested with maggots and create banquets of toxic invertebrates. Other waterfowl eating the maggots from these carcasses ingest large amounts of toxin, and are frequently found dead near by the original carcass. Immediate removal of carcasses is of paramount importance.

Chiplef placed tagged carcasses randomly throughout the marsh in order to estimate the efficiency of carcass removal. ${ }^{1}$ Retrieved tags indicated that removal efficiency of actual carcasses was $32 \%$. Tagged carcasses represented a small proportion of the actual carcasses and the evaluation was limited to two occasions. The efficiency of the removal should increase over time as efforts continue until most carcasses appear to have been picked up. Carcasses remain afloat for a period of days and the chance of repeatedly overlooking carcasses should diminish with each effort.

Eyebrow Marsh's trend of avian botulism will continue as many of the contributing factors are beyond the scope of wetland management. Many of the casualties are Mallards. Dabbling ducks make up the greatest percentage of mortality. Water level manipulation may aid in the prevention of an outbreak but it is not reliable as a management tool. Preventative measures require regular and thorough survey for carcasses 
commencing with a period of high numbers of flightless moulters and high daily ambient temperatures. Effective control of an outbreak necessitates the immediate and continual removal and disposal of carcasses until the disease has subsided. Initial casualties can be submitted to the Canadian Cooperative Wildlife Health Centre in Saskatoon for confirmation of the disease. Understanding the annual recruitment and loss of waterfowl over the long term would assist in determining whether current marsh management practices should change.

1. CHIPLEF, D. 1989. Evaluation of carcass collection and disposal as a management technique for responding to disease outbreaks in wild waterfowl. Alta. Rec., Parks and Wildlife Found. Proj., unpubl. report. 13 pp.
2. HUNTER, B.F. and W.E. CLARK. 1971. Waterfowl botulism management. Wildlife Management leaflet No. 14, Res. Agency of California, Dept. of Fish and Game. Sacramento, CA., $12 \mathrm{pp}$.

3. LOCKE, N.L. and M. FRIEND. 1987. Avian botulism. Pp. 83-93 in $\mathrm{M}$. Friend, Field guide to wildlife diseases. U.S. Dept. of Interior, Res. Publ. 167, Washington, DC.

4. SMITH-WINDSOR, T.B. and D.A. DUFFUS. 1981. Botulism monitoring and clean-up in Saskatchewan. Ducks Unlimited Can., unpubl. report, Regina. $21 \mathrm{pp}$.

5. WOBESER, G.A., S. MARSDEN and R.J. MACFARLANE. 1986. Occurrence of toxigenic Clostridum botulinum type $\mathrm{C}$ in the soil of Saskatchewan wetlands. Unpubl. report, Dept. of Pathology, WCVM, Saskatoon. $16 \mathrm{pp}$.

A cardinal, whistling spring to thaw but later finding himself mistaken, can retrieve his error by resuming his winter silence. A chipmunk, emerging for a sunbath but finding a blizzard, has only to go back to bed. But a migrating goose, staking two hundred miles of black night on the chance of finding a hole in the lake, has no easy chance for retreat. His arrival carries the conviction of a prophet who has burned his bridges. Aldo Leopold. 1949. A Sand County Almanac. Oxford. 